Отримано: 27 серпня 2018 р.

Прорецензовано: 07 вересня 2018 р.

Прийнято до друку: 13 вересня 2018 р. e-mail: o.i.joshi@nuwm.edu.ua

DOI: $10.25264 / 2311-5149-2018-10(38)-146-152$
Бредюк В. І., Джоші О. І. Прогнозування безробіття в Україні на основі методу Бокса-Дженкінса. Наукові записки Національного університету «Острозька академія». Серія «Економіка» : науковий журнал. Острог : Вид-во НаУОА, вересень 2018. № 10(38). C. 146-152.

Бредюк Володимир Ілліч,

кандидат технічних наук, доцент, доиент кафедри економічної кібернетики,

Національний університет водного господарства та природокористування

Джоші Олена Іванівна,

кандидат технічних наук, доцент кафедри економічної кібернетики,

Національний університет водного господарства та природокористування

\title{
ПРОГНОЗУВАННЯ БЕЗРОБІТТЯ В УКРАЇНІ НА ОСНОВІ МЕТОДУ БОКСА-ДЖЕНКІНСА
}

У статті виконано статистичний аналіз часового ряду чисельності безробітних в Україні. За допомогою візуального аналізу графіку часового ряду, аналізу графіка АКФ та узагальненого тесту Дікі-Фулера ідентифіковано модель часового ряду. Для побудови прогнозної моделі безробіття в Украӥні обтрунтовано застосування методу Бокса-Дженкінса. Розглянуто альтернативні прогнозні моделі й очінено їх параметри в середовищі економетричного пакету EViews. Побудовано прогноз чисельності безробітного населення в Україні.

Ключові слова: безробіття, часовий ряд, модель часового ряду, метод Бокса-Дженкінса, прогноз.

\section{Бредюк Владимир Ильич,}

кандидат технических наук, дочент, дочент кафедры экономической кибернетики, Национальный университет водного хозяйства и природопользования

\section{Джоши Елена Ивановна,}

кандидат технических наук, дочент кафедры экономической кибернетики, Национальный университет водного хозяйства и природопользования

\section{ПРОГНОЗИРОВАНИЯ БЕЗРАБОТИЦЫ В УКРАИНЕ НА ОСНОВЕ МЕТОДА БОКСА-ДЖЕНКИНСА}

В статье выполнен статистический анализ временного ряда численности безработных в Украине. С помощью визуального анализа графика временного ряда, анализа графика АКФ и обобщенного теста Дики-Фулера идентифицировано модель временного ряда. Для построения прогнозной модели безработицы в Украине обосновано применение метода Бокса-Дженкинса. Рассмотрены альтернативные прогнозные модели и оценені их параметры в среде эконометрического пакета EViews. Построен прогноз численности безработного населения в Украине.

Ключевые слова: безработииа, часовой ряд, модель часового ряда, метод Бокса-Дженкинса, прогноз.

\section{Volodymyr Brediuk}

PhD in Technical Sciences, Associate Professor, Associate Professor at the Department of Economic Cybernetics National University of Water and Environmental Engineering

\section{Olena Joshi,}

PhD in Technical Sciences, Associate Professor at the Department of Economic Cybernetics National University of Water and Environmental Engineering

\section{FORECASTING OF UNEMPLOYMENT IN UKRAINE ON THE BASIS OF THE BOX-JENKINS METHOD}

The article analyzes the main modern tendency and approaches to the economic-mathematical modeling of unemployment as a complex socio-economic phenomenon. The analysis of modern domestic and foreign research in this field shows that this task is being given sufficient attention, while the most popular approach for forecasting of unemployment remains an econometric approach, based on a quantitative description of causal relationships between unemployment rates and other factors. At the same time, there are practically no studies based on the use of the theory and tools of time series, which determines the relevance of this direction in the study of unemployment in Ukraine.

In the process of the study, a statistical analysis of the time series of the number of unemployed people in Ukraine was made, which found that the time series of annual unemployment data in Ukraine for the period from 2000 to 2017 may be represented by an additive model of a non-stationary time series that includes trend and random components. Proceeding from this, the method of Box-Jenkins was chosen for short-term forecasts for the number of unemployed in Ukraine. The 
choice of this method was also based on its universality, since it does not provide any particular single time-series structure on the basis of which the forecast is made.

Using the Box-Jenkins methodology, several alternative specifications of predictive ARIMA models are considered. Estimation of the parameters of these models, their statistical analysis and the verification of adequacy are made with the help of the econometric package EViews 8. Among all possible specifications for forecasting the number of unemployed, the ARIMA model $(1,2,0)$ has been finally selected as the one that satisfies all the criteria for adequacy and efficiency. Based on this model, the forecast of the number of unemployed in Ukraine in 2018 is constructed, which correlates well enough in quantitative and qualitative terms with the general tendency of unemployment growth in Ukraine over the last 3 years.

Key words: unemployment, time series, model of the time series, Box-Jenkins method, forecast.

Постановка проблеми. Зайнятість і безробіття населення є одними з найважливіших макроекономічних показників - індикаторів, що разом з обсягом ВВП і рівнем цін визначають економічну кон'юнктуру національного ринку, впливають на рівень життя населення, забезпечують добробут кожного громадянина країни та характеризують «економічне здоров'я» країни.

Питання зайнятості і безробіття в кризових умовах, що склались на українському ринку праці, є досить важливими й актуальними. Їх глибоке вивчення - це вагомий інструмент регулювання економічної і соціальної політики держави. Зменшення кількості робочих місць унаслідок скорочення виробництва, зменшення реальних доходів громадян призводять до підвищення чисельності безробітних, суттєвих негативних економічних наслідків і створення соціальної напруги в суспільстві. Вирішення проблем зайнятості і безробіття населення є однією з головних цілей будь-якого прогресивного суспільства.

Аналіз останніх досліджень і публікацій. Дослідженнями проблем функціонування та розвитку вітчизняного ринку праці з використанням методів економіко-математичного моделювання займалися такі вітчизняні вчені, як 3. Бараник, А. Васильєв, В. Вітлінський, В. Вовк, В. Геєць, Л. Гур'янова, Т. Клебанова, С. Левицький, І. Лук'яненко, М. Скрипниченко та ін. Фундаментальні основи функціонування ринку праці й економетричне моделювання його основних індикаторів для країн із ринковою та трансформаційною економікою були досліджені у працях зарубіжних учених, зокрема К. Біна, О. Бланчарда, А. Варне, Д. Галі, К. Гренджера, О. Даметте, Д. Емерсона, Д. Куага, А. Нібура, А. Спайта, С. Фішера, Б. Хансена та ін.

Аналіз останніх вітчизняних досліджень у цій галузі показує, що під час дослідження безробіття в Україні, як соціально-економічного явища, здебільшого використовують методи кореляційно-регресійного аналізу, які базуються на принципі причинно-наслідкового взаємозв'язку між різними економічними показниками, які характеризують це явище. Зазначимо, що такий підхід не завжди може давати позитивні результати внаслідок або слабкої кореляції між відібраними показниками, або через банальну нестачу необхідної надійної статистичної інформації.

Водночас практично немає досліджень, у яких застосовують методи аналізу і прогнозування безробіття на основі методології часових рядів. Таким чином, залишається відкритим питання, на скільки вдалими та надійними можуть бути методи аналізу та прогнозування, які використовують методи й інструментарій часових рядів. Саме цим і ми пояснюємо актуальність і доцільність нашої роботи.

Метою дослідження є виявлення можливості й ефективності застосування методу Бокса-Дженкінса для прогнозування чисельності безробітних в Україні. Досягнення поставленої мети передбачає розв'язання таких завдань:

1) відбір необхідних статистичних даних для дослідження безробіття;

2) ідентифікація моделі часового ряду;

3) попередній відбір альтернативних прогнозних моделей у межах методології Бокса-Дженкінса;

4) побудова відібраних прогнозних моделей часового ряду та перевірка на адекватність;

5) порівняльний аналіз альтернативних прогнозних моделей і формування рекомендацій щодо їх використання;

6) побудова прогнозу на 2018 рік.

Виклад основного матеріалу. Однією з основних характеристик безробіття, що застосовується в практиці статистичного аналізу та прогнозування, і який досліджувався у роботі, є чисельність безробітних. Для побудови прогнозних моделей було обрано часовий ряд, що характеризує динаміку чисельності безробітного населення України за 2000-2017 рр. [7]. Статистичні дані щодо чисельності безробітних за означений період і їх графічне представлення наведено нижче в таблиці 1 і на рис. 1. 
Динаміка чисельності безробітних в Україні за 2000-2017 pp.

\begin{tabular}{|c|c|}
\hline Рік & Безробітне населення (за методологісю МОП) у віці 15-75 років, тис. осіб \\
\hline 2000 & 2655,80 \\
\hline 2001 & 2455,00 \\
\hline 2002 & 2140,70 \\
\hline 2003 & 2008,00 \\
\hline 2004 & 1906,70 \\
\hline 2005 & 1600,80 \\
\hline 2006 & 1515,00 \\
\hline 2007 & 1417,60 \\
\hline 2008 & 1425,10 \\
\hline 2009 & 1958,80 \\
\hline 2010 & 1785,60 \\
\hline 2011 & 1732,70 \\
\hline 2012 & 1657,20 \\
\hline 2013 & 1576,50 \\
\hline 2014 & 1847,60 \\
\hline 2015 & 1654,70 \\
\hline 2016 & 1678,20 \\
\hline 2017 & 1698,00 \\
\hline
\end{tabular}

Із метою ідентифікації моделі часового ряду для наведених даних було використано такі підходи:

- візуальний аналіз графіка часового ряду (рис. 1);

- аналіз графіка автокореляційної функції (рис. 2);

- узагальнений тест Дікі-Фулера.

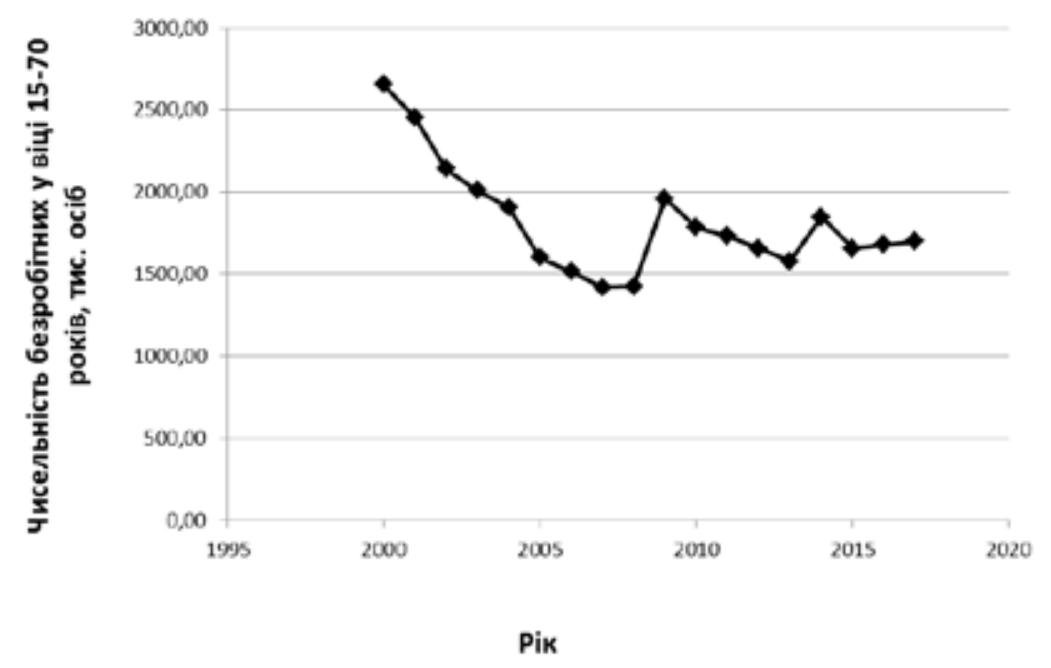

Рис. 1. Динаміка чисельності безробітних в Україні за 2000-2017 рр.

Візуальний аналіз графіка часового ряду дозволив висунути припущення, що цей часовий ряд є нестаціонарним і характеризується наявністю тренду. Аналіз корелограми, наведеної на рис. 2, також підтверджує існування в нашому часовому ряду трендової складової. Результати узагальненого тесту ДікіФулера, виконаного в середовищі пакету EViews, наведено на рис. 3. Аналіз цих результатів показав, що розрахункове значення ADF-статистики $(-2,335)$ перевищує критичне значення статистики Мак-Кінона для рівня значущості 5\% $(-3,710)$, що дозволяє зробити висновок, що ряд річних даних чисельності безробітних є справді нестаціонарним. 


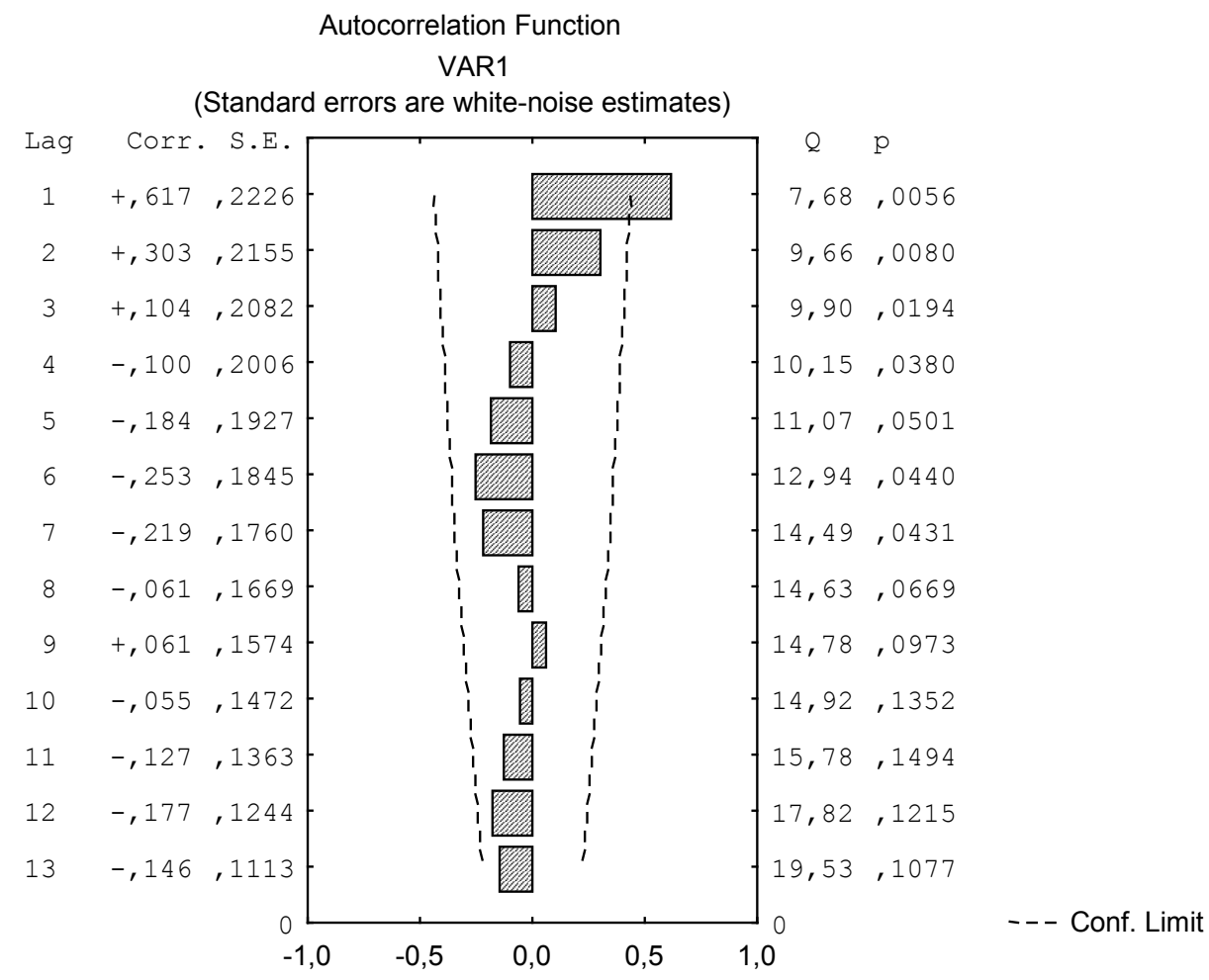

Рис. 2. Графік автокореляційної функції

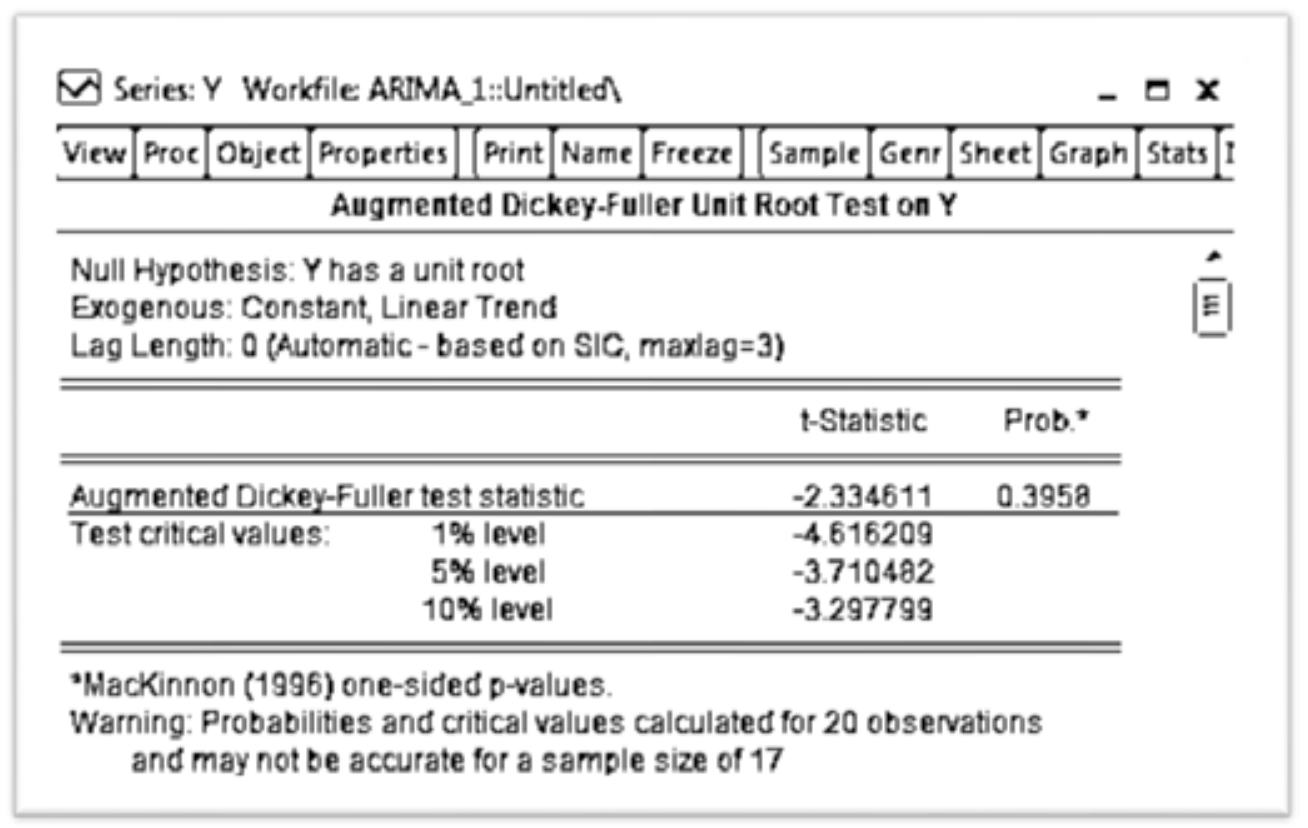

\section{Рис. 3. Результати узагальненого тесту Дікі-Фулера}

Таким чином, часовий ряд річних даних чисельності безробітних в Україні за період 2000-2017 років можна ідентифікувати як нестаціонарний, адаптивна модель якого містить трендову та випадкову складові.

Для побудови прогнозної моделі було використано метод Бокса-Дженкінса. Вибір цього методу грунтувався на універсальності цієї методології, оскільки в ній не передбачається якась одна особлива структура часового ряду, на основі якої здійснюють прогноз.

Із метою виключення з часового ряду детермінованої трендової складової було спочатку здійснено перехід від вихідного часового ряду до ряду перших різниць. Оскільки не вдалося позбутися детермінованої складової, то було здійснено перехід до ряду других різниць (рис. 4). 


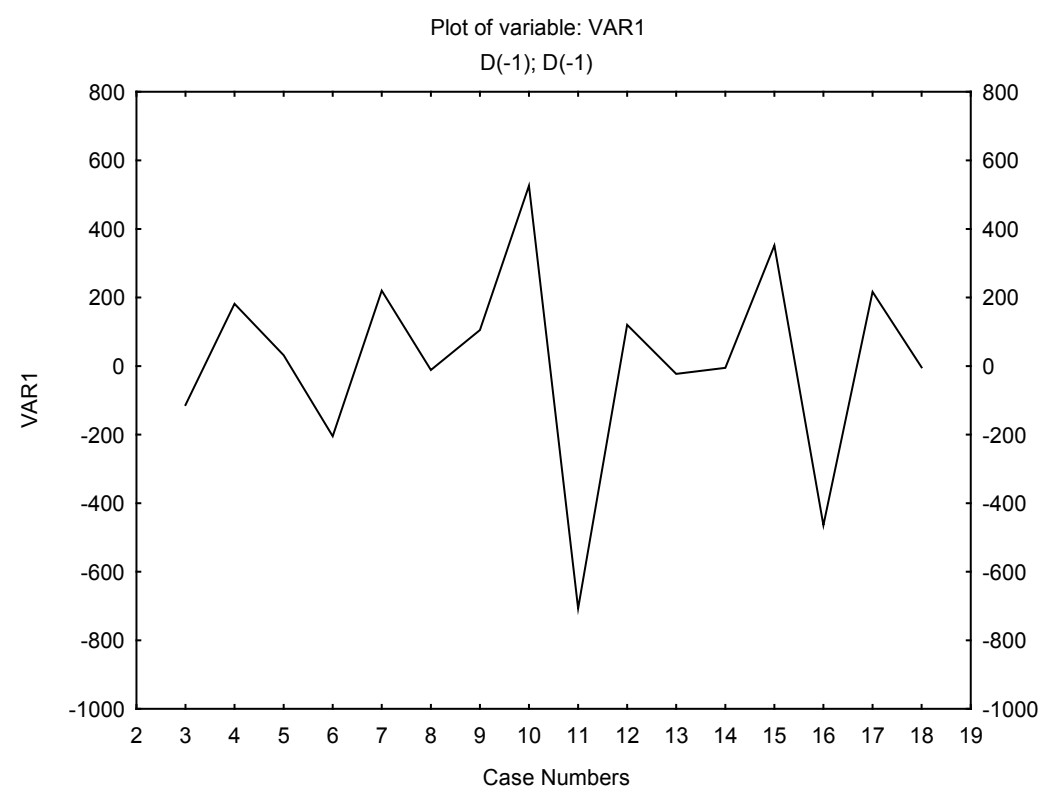

Рис. 4. Графік часового ряду других різниць

Як видно з цього графіка перетворений ряд других різниць достатньо близький до графіка стаціонарного часового ряду, причому варіації значень других різниць однозначно відбуваються навколо деякого середнього значення, яке дорівнює нулю. Виходячи з цього, під час подальшого оцінювання параметрів різних варіантів ARIMA-моделей із розгляду було вилучено константи моделі. Для визначення типу прогнозної моделі - AR(p), MA(q) або ARMA(p,q), а також їхніх характеристик (p,q), було побудовано графіки вибіркових функцій автокореляції та часткової автокореляції (рис. 5, рис. 6).

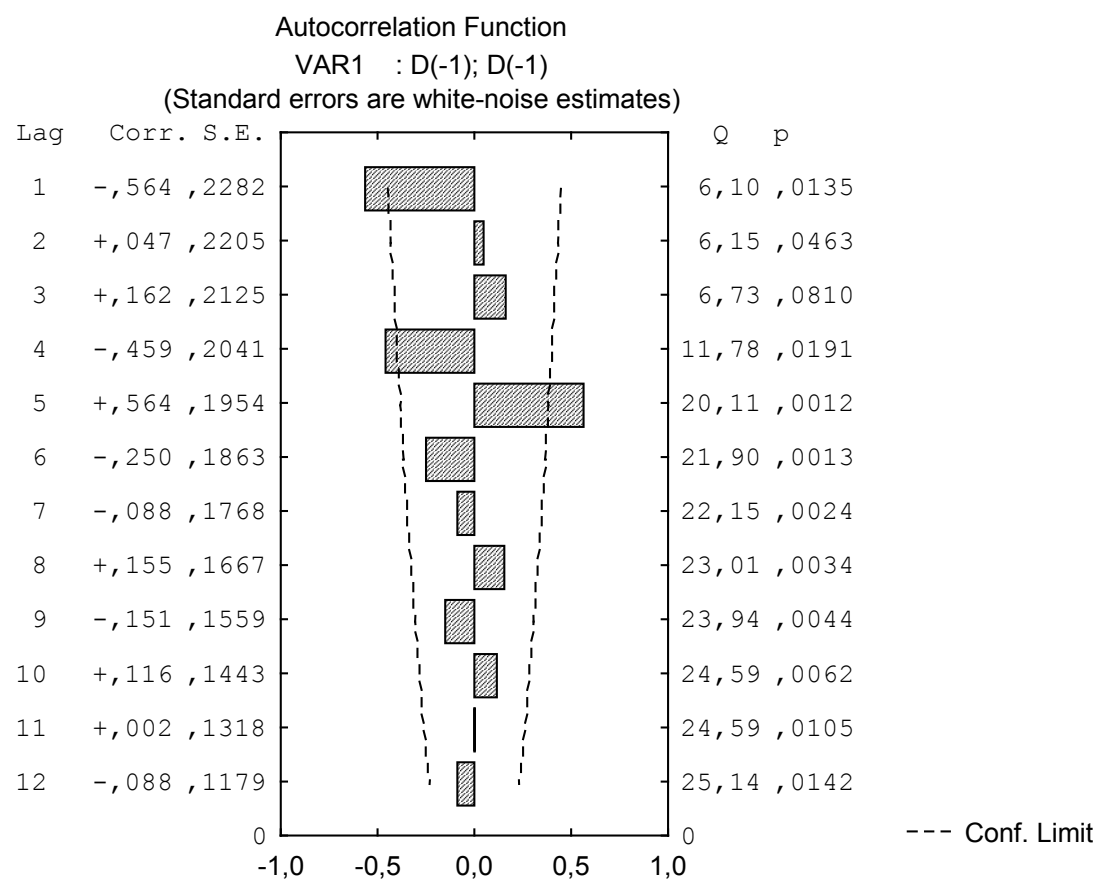

Рис. 5. Графік автокореляційної функції для ряду других різниць

На основі аналізу цих корелограм було розглянуто такі альтернативні варіанти ARIMA-моделей:

- $\operatorname{ARIMA}(1,2,0)$;

- ARIMA $(4,2,0)$;

- ARIMA $(0,2,1)$;

- ARIMA $(0,2,4)$;

- ARIMA $(1,2,1)$; 
- $\operatorname{ARIMA}(4,2,4)$.

Оцінювання параметрів обраних варіантів моделей було здійснено в середовищі економетричного пакету EViews. У результаті вдалось отримати тільки два варіанти моделі, які мали всі статистично значущі параметри (таблиця 2).

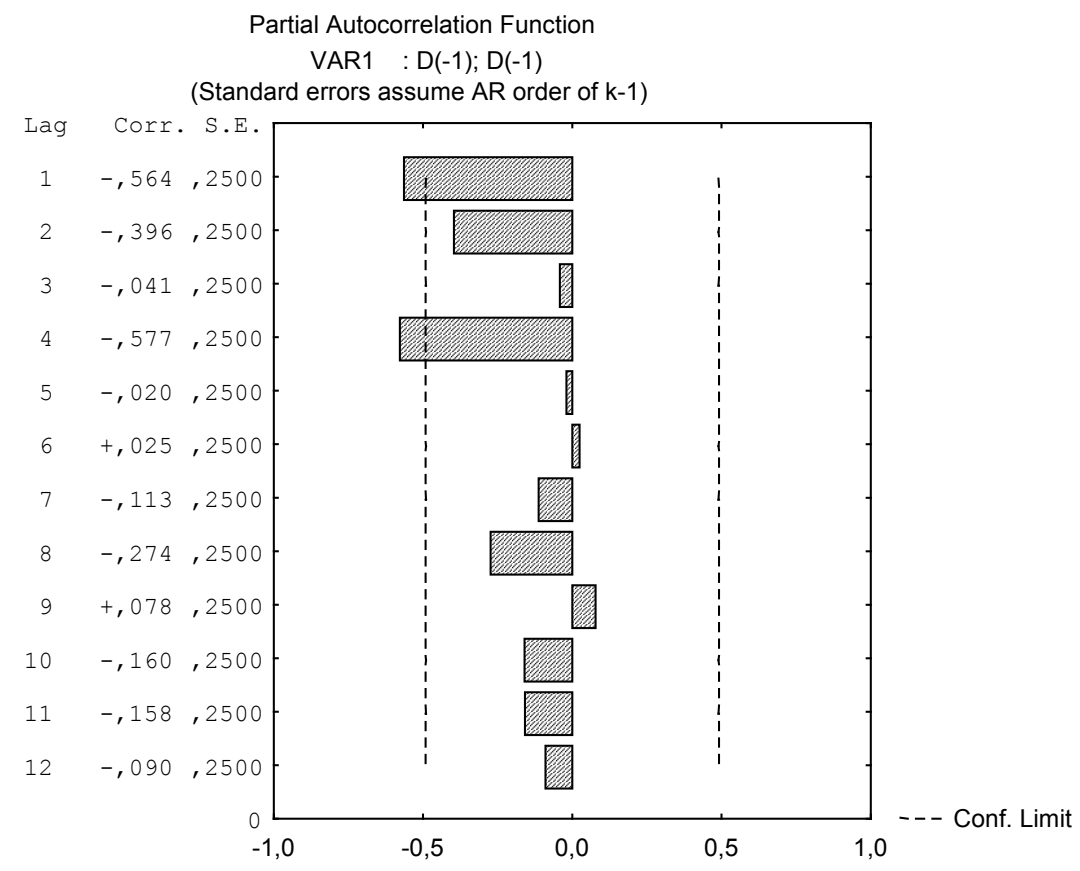

Рис. 6. Графік часткової автокореляційної функції для ряду других різниць

\begin{tabular}{|l|l|}
\multicolumn{1}{|c|}{ Сезультати оцінювання ARIMA-моделей } \\
\hline ARIMA $(1,2,0)$ & \multicolumn{1}{c|}{ Оцінена модель } \\
\hline ARIMA $(0,2,1)$ & $\Delta_{2} \mathrm{y}_{\mathrm{t}}=-0,559 \Delta_{2} \mathrm{y}_{\mathrm{t}-1}+\varepsilon_{\mathrm{t}}$ \\
\hline & $\Delta_{2} \mathrm{y}_{\mathrm{t}}=\varepsilon_{\mathrm{t}}-0,801 \varepsilon_{\mathrm{t}-1}$ \\
\hline
\end{tabular}

Переходячи від других різниць до фактичних значень часового ряду, отримуємо відповідно такі оцінені ARIMA-моделі:

$$
\begin{aligned}
& \mathrm{y}_{\mathrm{t}}=1,441 \mathrm{y}_{\mathrm{t}-1}-0,118 \mathrm{y}_{\mathrm{t}-2}-0,559 \mathrm{y}_{\mathrm{t}-3}+\varepsilon_{\mathrm{t}},(1) \\
& \mathrm{y}_{\mathrm{t}}=2 \mathrm{y}_{\mathrm{t}-1}-\mathrm{y}_{\mathrm{t}-2}+\varepsilon_{\mathrm{t}}-0,801 \varepsilon_{\mathrm{t}-1} \text {. (2) }
\end{aligned}
$$

Аналіз адекватності наведених моделей показав, що тільки модель ARIMA $(1,2,0)$ відповідає всім критеріям адекватності. Таким чином, саме модель (1) є такою, що може бути рекомендованою для прогнозування чисельності безробітних на 2018 рік. Використовуючи вираз (1) для моделі ARIMA $(1,2,0)$, було обчислено розрахункові значення чисельності безробітних, відносні середні похибки прогнозу та прогнозне значення чисельності безробітних на 2018 рік. Водночас похибки прогнозу склали:

- 0,109 (10,9\%) для всієї вибірки;

- 0,085 (8,5\%) для контрольної вибірки (останні 5 спостережень).

Точкове прогнозне значення чисельності безробітних на 2018 рік становить 1719,9 тис. осіб. Нижня межа інтервального прогнозу з рівнем довіри 0,95 складає 1213,1 тис. осіб, а верхня - 2226,7 тис. осіб.

\section{Висновки.}

1. Часовий ряд річних даних щодо безробіття в Україні за період із 2000 по 2017 роки може бути представлений адитивною моделлю нестаціонарного часового ряду, який містить трендовий і випадковий компоненти.

2. Для побудови короткотермінових прогнозів для чисельності безробітних в Україні можна рекомендувати застосування методології Бокса-Дженкінса.

3. Використовуючи методологію Бокса-Дженкінса, у роботі розглянуто декілька альтернативних специфікацій ARIMA-моделей. Серед усіх можливих специфікацій для прогнозування чисельності безро- 
бітних остаточно відібрано модель ARIMA $(1,2,0)$, як таку, що відповідає всім критеріям адекватності й економічності.

4. На основі моделі ARIMA $(1,2,0)$ побудовано прогноз чисельності безробітних в Україні на 2018 рік. Таким чином, у 2018 році чисельність безробітних в Україні буде становити у середньому 1719,9 тис. осіб, при цьому з імовірністю 0,95 ця чисельність може коливатися в межах від 1213,1 тис. осіб до 2226,7 тис. осіб. Слід зазначити, що точкове прогнозне значення 1719,9 тис. осіб достатньо добре корелює в кількісному та якісному плані з загальною тенденцією зростання безробіття в Україні за останні 3 роки (рис. 1). Точність прогнозу для контрольної частини вибірки становить для обраної моделі 8,5\%.

\section{Література:}

1. Бідюк П. І., Романенко В., Тимощук О. Аналіз часових рядів: навч. посібник. Киъв: Політехніка, 2010. $317 \mathrm{c}$.

2. Васильєв О. Прогнозування рівня безробіття в Україні. Економіка Украӥни. 2012. № 4. С. 41-46.

3. Козицька I. Є. Статистичний аналіз безробіття в управлінні соціально-економічними процесами в Україні. Матеріали ХІ Всеукраӥнської науково-практичної інтернет-конферениї̈ «Математичні методі та моделі в оподаткуванні, бізнесі, економіщі: Збірник тез доповідей. 1-8 грудня 2015 р. Ірпінь: Національний університет ДФС України, 2016. С. 211-216.

4. Максимчук Є. А. Статистичні дослідження рівня безробіття в Хмельницькій області. Матеріали XI Всеукраӥнської науково-практичної інтернет-конференцї̈ «Математичні методі та моделі в оподаткуванні, бізнесі, економічі: Збірник тез доповідей. 1-8 грудня 2015 р. - Ірпінь: Національний університет ДФС України, 2016. - C. 244-248.

5. Окара Д. В. Економетричне моделювання регіональних ринків праці України. URL: hhtp://psae-jrnl.nau. in.ua/journal/2_58_2017_ukr/28.pdf (Дата звернення : 8 вересня 2018 р.).

6. Савчук Л. О., Гаврилюк А. В. Економіко-математичний аналіз рівня зайнятості та безробіття населення у Хмельницькій області. Наука й економіка. 2014. № 2. С. 192-196.

7. Сайт Державної служби статистики України. URL: hhtp://www.ukrstat.gov.ua. (Дата звернення : 3 вересня 2018 p.).

8. Хлівна І. В. Моделі аналізу та прогнозування зайнятості населення. Агросвіт. 2013. № 11. С. 28-33.

9. Тахтарова К. А. Прогнозування рівня безробіття в Україні. Економіка і організація управління. 2014. № 3-4. C. 269-276. 